\title{
Brazilians sentenced to sewage-related diseases
}

Édison Carlos $^{1}$

There is no furthest behind infrastructure in Brazil than the lack of sewage disposal, particularly the shortage of services for treating water, and for collecting and treating waste. The scarcity of these essential services to human dignity has been plaguing millions of Brazilians, as indicated by the data of the National Sanitation Information System 2014(1). We have 35 million Brazilians without access to services for treating water, where half the population has no sewage collection and only $40 \%$ of the waste collected in this country is treated. The shortage of sewage disposal affects all of us.

The lack of these services can be realized everywhere, even in the most noble areas of the country, but we may be sure that the greatest impacts happen in low-income families, which live closer to sewers, i.e., in the outskirts, in the so-called "irregular areas". Many noble neighborhoods were built with no concern for the health issues, and people coexist with septic tanks in the yard until the current days. Regarding the irregular areas, in Brazil, there were more than 11 million people dwelling in these areas, the large majority using water from illegal connections and throwing the sewers in the open air, in cesspits or water courses ${ }^{(2)}$.

The framework of disinterest of the state in developing serious sewage disposal policies produces brutal impacts to the health of Brazilians as well as a generalized pollution to the hydric resources. Only in 2013, the Brazilian Ministry of Health announced that there was an amount greater than 400.000 hospitalizations for gastrointestinal diseases, where most children were aged between zero and five years. It has shown outbreaks of diarrhea, worm infections, hepatitis A, and more recently diseases caused by the Aedes aegypti. Experts increasingly associate the explosion of Dengue, Zika and Chikungunya cases with the habit of people, such as the way to store water, with the lack of collection and treatment of sewage, with the scarcity of proper destination of part of household waste and with the poor infrastructure of drainage of rain water.

It is worth stating that there are advances, and various cities are striving to solve the problem in question, but it is still very little compared to the challenge. Fortunately, 2016 has been highlighted by more debates, mainly due to the fact that the Ecumenical Fraternity Campaign of the Catholic Church has placed the sewage disposal as theme, thereby bringing the discussions to the farthest corners of the country.

In summary, a country with no sewage disposal has no good health indicators, has no clean rivers and beaches, has good schooling levels, nor even productivity, does not expand tourism, does not value its buildings, and has no dignity. Thus, we need to strengthen the fight, since the country requires it!

\section{References}

1. Sistema Nacional de Informações sobre Saneamento. Diagnóstico dos Serviços de Água e Esgotos - 2014 [Internet]. 2014 [citado 2016 jun 7]. Disponível em: http://www.snis.gov.br/diagnostico-agua-e-esgotos/ diagnostico-ae-2014

2. Instituto Brasileiro de Geografia e Estatística. Sinopse do Censo Demográfico de 2010. Rio de Janeiro: IBGE; 2011.

\footnotetext{
${ }^{1}$ Executive chairman of the Instituto Trata Brasil. São Paulo, SP, Brazil. 